\title{
The Influence of Bank Credit on Financial Structure and Financial Return for the Romanian Companies Active in Car Parts Distribution
}

\author{
Phd. Student Baciu (Boanta) Rodica ${ }^{1}$, Ph.D. Professor Brezeanu Petre ${ }^{1} \&$ Phd Lecturer Adrian Simon ${ }^{2}$ \\ ${ }^{1}$ The Bucharest University of Economic Studies Department of Finance, Romania \\ ${ }^{2}$ University of Medicine, Pharmacy, Science and Tehnology of Tg-Mures, Romania \\ Correspondence: Phd. Student Baciu (Boanta) Rodica, The Bucharest University of Economic Studies Department of \\ Finance, Romania
}

Received: April 10, 2020

Accepted: May 9, 2020

Online Published: May 10, 2020

doi:10.5430/afr.v9n2p73

URL: https://doi.org/10.5430/afr.v9n2p73

\begin{abstract}
In this research, we analyze the dependence between financial return (as a dependent, endogenous variable) and bank credit (the volume of bank credits and the cost of borrowed capital, both expressed as independent, exogenous variables), applicable to Romanian companies that deal in the wholesale trade sector of parts and accessories for motor vehicles. Using the 2008-2017 time series panel data model on companies in this sector, we conclude that there is a relatively modest link between financial performance and bank credit., thus illustrating that the main factors generating financial returns are asset rotation (long-term investment efficiency in income generation) as well as operational profitability margin. We also discuss the diagnosis of capital returns in the analyzed sector by decompiling it into margins, rotation and capital structure (DuPont) rates.
\end{abstract}

Keywords: Return on Equity (ROE), financial structure, ROA retutn on assets, bank credit

JEL Classification : 016.

\section{Introduction and Literature}

In this paper, we analyze the dependence between financial return (as a dependent, endogenous variable) and bank credit (the volume of bank credits and the cost of borrowed capital, both expressed as independent, exogenous variables). To do so, we apply the panel data model to all companies operating in the wholesale of car parts distribution (NACE: 4531) by distributing the companies into clusters (homogeneous classes), depending on the level of income obtained. Throughout this section, we discuss the most important models of financial return decomposition, as well as the reason why the bank credit (volume and cost of capital) should play an essential role in its evolution. We further describe the time series and the methodology argumentation in the next section and present our conclusions at the end.

The return on equity (ROE) is one of the most important financial indicators used by shareholders to analyze the return on invested capital (Cace et al., 2011). According to Alcock and Steiner (2017), a superior return on equity coupled with reinvestment of profits in the company will help accelerate its growth and development. If shareholders decide to reduce the distribution of short-term dividends and reinvest additional capital in positive value-added projects, it will help increase the long-term sustainable development rate (Vijayakumaran, 2018). On the other hand, increasing the distribution of dividends can contribute to short-term shareholders' satisfaction but will limit the company's long-term growth potential through over-indebtedness in financing long-term investment projects (Muradoğlu and Sivaprasad, 2012). Miglo (2016) emphasized that the financial return should exceed the shareholders' opportunity cost (the second-best option for capital investment) given the country, sector, and risk incurred by the investing company (Wibowo, 2005). Other researchers have shown that poor financial performance may be one of the main causes of companies' inability to pay, as well as of an increased insolvency risk (Ting, 2012). If the insolvency risk materializes, then the treasury of the company will depend to a significant extent on the external resources borrowed from credit institutions and business partners (credit suppliers), fueling pressures on operational cash (Anthony, 2011). This generates an additional risk in countries marked by high inflation and rising interest rates, thus increasing the vulnerability of companies in the context of increasing financing costs (Vintila et al., 2018). On the other hand, a series of studies have indicated that higher financial returns, as compared with historical values (sectoral average value over the past ten years), will generate negative adjustment pressures as a result of the 
trend towards long-term return to the average value, especially in sectors where entry barriers are low (Skopljak and Luo, 2012). This effect is caused by the additional competition that is attracted by the short-term financial returns as compared with the initial investment (Avci, 2016). We also notice that Guo and Luo (2017) tried to show that an efficient credit market would induce more firms to export and then increase the international trade. According with these last-mentioned authors, firms might not be able to get the credit to export even although they are profitable enough from the foreign market.

The analysis of the return on capital comprises two categories of efficiency rates (Stancu, 2012):

- Economic profitability rate (i.e., return on assets, calculated by reporting the result acquired at asset level (ROA $=$ net output $/$ assets)); and

- $\quad$ Financial return ratio (calculated by reporting net income to equity level, ROE = net result / equity) and effective interest rate ( $\mathrm{Rd}=$ interest expenses / bank debts).

A company-owned asset is the result of all investment decisions, which are funded by equity (capital contribution and internal resources) and borrowed capital (contracted debt). Economic return rate (ROA) reflects the profitability of the economic asset, the return on equity (ROE) reflects the profitability of equity, and the interest rate (Rd) reflects the profitability of borrowed capital. Starting from the equilibrium of balance sheets $(A=C P+D)$, we get the link between economic profitability, as a result of financial return, and capital remuneration (Burns et al., 2008; Halsey, 2001).

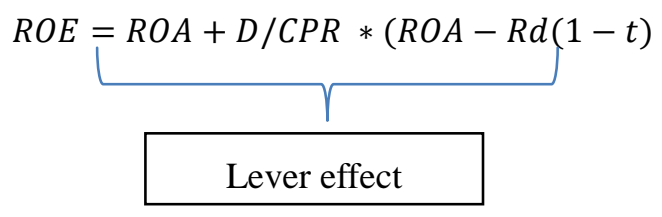

Using the DuPont model with five variables enables us to better evaluate and understand the financial performance component (Colbu 2013; Kasilingam and Jayabal 2012) where the opposite effect is apparent between the positive lever effect on the financial profitability (the increase of the indebtedness implies the reduction of capitalization, and, implicitly, the amplification of financial return by the base effect, Kim et al. (2005)) and that of financial indebtedness (the increase in indebtedness fuels the increase in interest rates and, implicitly, the erosion of operational profit (Nissim \& Penman, 2003; Beard \& Sias, 1997).

\begin{tabular}{|c|c|c|}
\hline $\begin{array}{c}\text { Operational margin: } \\
\text { Indicates how profitable the } \\
\text { sales are and what profit } \\
\text { margin the company } \\
\text { achieves by carrying out its } \\
\text { core business. An } \\
\text { endogenous variable, } \\
\text { dependent on management } \\
\text { decisions. }\end{array}$ & $\begin{array}{l}\text { Asset rotation: } \\
\text { Reflects company's } \\
\text { ability to generate } \\
\text { sales of its assets. An } \\
\text { endogenous variable, } \\
\text { dependent on } \\
\text { management } \\
\text { decisions. }\end{array}$ & $\begin{array}{l}\text { Reflects the capital } \\
\text { structure and the lever } \\
\text { effect, with immediate } \\
\text { positive effect on the ROE } \\
\text { but is quite the inverse in } \\
\text { the medium to long term } \\
\text { because of the increase in } \\
\text { financial indebtedness. }\end{array}$ \\
\hline \multicolumn{3}{|c|}{$R O E=E A T / C P R=E A T / E B T * E B T / E B I T * E B I T / C A * C A / A * A / C P R$} \\
\hline $\begin{array}{l}\text { Fiscal burden: Varies in } \\
\text { inverse proportion } \\
\text { toward the ratio of EAT } \\
\text { and EBT. The tax regime } \\
\text { is exogenous, and the } \\
\text { company cannot control } \\
\text { it. }\end{array}$ & \multicolumn{2}{|c|}{$\begin{array}{l}\text { Financial burden: Varies in inverse proportion toward the } \\
\text { ratio of EBT and EBIT. Interest rates depend on the } \\
\text { context of the financial system, but the company may have } \\
\text { hedging instruments to cover variable interest rate risk } \\
\text { (e.g., forward contracts). At the same time, a higher level } \\
\text { of operational margin allows a very generous degree of } \\
\text { coverage for interest expenses. }\end{array}$} \\
\hline
\end{tabular}


where

- $\quad$ EAT $=$ earnings after tax

- $\quad$ CPR = own equity

- $\quad$ EBT = gross result (“earnings before tax")

- $\quad$ EBIT = operating result (English "earnings before interest and tax")

Practically speaking, the debt ratio generates two adverse effects on the financial performance: positive (by increasing financial return as a result of the leverage effect) and negative (by increasing the financial burden as a result of the increase in the financing cost as indebtedness increases).

\section{Description of the Sample and Methodology}

\subsection{Description of the Sample}

On the basis of the financial statements submitted to the Ministry of Public Finance by the companies that are active in the sector of wholesale trade of motor vehicle parts and accessories (NACE: 4531), we notice the following general trends (as illustrated in Table 1):

- $\quad$ The number of active companies (recording revenues) is steadily decreasing, from 2,861 firms in year 2008 to 2,137 in year 2017.

- The level of revenues reported by the entire sector is characterized by a steady increase (except for the stabilization recorded in years 2009 and 2017), from RON 6.1 billion (in year 2008) to RON 10.3 billion (in year 2017).

- The evolution of profitability and financial/economic return indicators shows a downward trend over the period 2008-2012, followed by an increase over the next four years; and

- Against the backdrop of constant revenue growth, capital requirements have increased proportionally by increasing indebtedness, from 58.12\% (in 2008) to nearly 67\% (in 2015), followed by a decrease to $61 \%$ as a result of the reinvestment of profits.

Table 1. Evolution of companies in the sector of wholesale trade of parts and accessories for motor vehicles (NACE: 4531)

\begin{tabular}{|c|c|c|c|c|c|c|c|c|c|c|}
\hline $\begin{array}{c}\text { Indicator } \\
\text { (million } R O N \\
\text { values) }\end{array}$ & 2017 & 2016 & 2015 & 2014 & 2013 & 2012 & 2011 & 2010 & 2009 & 2008 \\
\hline $\begin{array}{l}\text { Number of } \\
\text { active } \\
\text { companies }\end{array}$ & 2,137 & 2,115 & 2,138 & 2,120 & 2,173 & 2,201 & 2,119 & 2,309 & 2,440 & 2,861 \\
\hline Total Revenues & 10,338 & 10,328 & 9,047 & 8,138 & 7,428 & 7,260 & 7,198 & 7,157 & 6,084 & 6,128 \\
\hline Income index \% & $0.1 \%$ & $14.1 \%$ & $11.17 \%$ & $9.56 \%$ & $2.31 \%$ & $0.86 \%$ & $0.57 \%$ & $17.64 \%$ & $-0.72 \%$ & \\
\hline $\begin{array}{l}\text { Average } \\
\text { turnover }\end{array}$ & 4.87 & 4.83 & 4.23 & 3.84 & 3.42 & 3.30 & 3.40 & 3.10 & 2.49 & 2.14 \\
\hline Net result (\%) & $3.57 \%$ & $1.1 \%$ & $2.36 \%$ & $1.50 \%$ & $0.50 \%$ & $0.43 \%$ & $2.80 \%$ & $2.28 \%$ & $2.62 \%$ & $3.23 \%$ \\
\hline $\begin{array}{c}\text { Return on } \\
\text { equity (ROE) }\end{array}$ & $12.5 \%$ & $5.2 \%$ & $10.36 \%$ & $6.10 \%$ & $2.05 \%$ & $1.70 \%$ & $10.61 \%$ & $8.59 \%$ & $8.41 \%$ & $13.72 \%$ \\
\hline $\begin{array}{l}\text { Return on assets } \\
\text { (ROA) }\end{array}$ & $5.1 \%$ & $1.15 \%$ & $3.47 \%$ & $2.10 \%$ & $0.68 \%$ & $0.58 \%$ & $3.92 \%$ & $3.07 \%$ & $3.26 \%$ & $4.56 \%$ \\
\hline Debt ratio & $61.2 \%$ & $64.8 \%$ & $66.8 \%$ & $65.4 \%$ & $66.8 \%$ & $65.3 \%$ & $62.2 \%$ & $63.4 \%$ & $60.4 \%$ & $58.1 \%$ \\
\hline Total jobs & 17,296 & 17,127 & 16,350 & 15,755 & 16,159 & 15,889 & 15,266 & 15,718 & 15,021 & 16,587 \\
\hline $\begin{array}{c}\text { Market share } \\
\text { companies' } \\
\text { turnover > EUR } \\
50 \text { million }\end{array}$ & $34.7 \%$ & $34.1 \%$ & $33.7 \%$ & $29.9 \%$ & $27.4 \%$ & $19.4 \%$ & $22.6 \%$ & $25.1 \%$ & $19.9 \%$ & $7.1 \%$ \\
\hline
\end{tabular}

Source: Ministry of Public Finance, National Trade Register Office, data processed by the author 
To analyze the components of the financial performance (return) according to the five variables as shown in the above-described DuPont model, the information in extended financial statements (especially regarding the profit and loss account) is necessary. This is why companies operating in the sector of wholesale trade of parts and accessories for motor vehicles (NACE: 4531) have been selected, for which financial statements in extended format are available for each of the financial years of the analyzed period (2008-2015). Thus, 153 companies have been identified that correspond to the above-mentioned criteria: they are companies with a turnover of more than EUR 1 million and that generate a consolidated market share of approximately $85 \%$ at the level of the entire industry. The components of financial profitability (return) are calculated for each year and are illustrated in the following table.

\subsection{Methodology}

To analyze the dependence between financial return (as dependent, endogenous variable) and bank credit (the volume of bank credits and the cost of borrowed capital, both expressed as independent, exogenous variables), the following stages have been completed:

- $\quad$ All the companies in the analyzed sector that reported financial statements for each of the financial years belonging to the period considered were taken into account (to remove the survival effect);

- Considering the need for debt breakdown depending on the creditors (banks, supplier, tax), only companies with revenues over EUR 1 million were considered, given that only those companies submitted their financial statements in extended format.

- The resulting sample consisted of 165 companies, which generate a consolidated turnover of RON 7.4 billion, or almost $70 \%$ of the revenues recorded at sectoral level.

- The thus remaining companies were divided into five different groups, depending on the level of revenues, as follows: EUR 1-2.5 million, EUR 2.5-5 million, EUR 5-10 million, EUR 10-50 million, + EUR 50 million.

- The model variables were calculated for each cross-sectional group related to each financial exercise of the period from 2008 to 2017 (10 time series).

Given that the regression equation contains both time series and cross-sectional data, a model with panel data was used, with 50 observations in total (10 time series and 5 cross-sectional data). According to Baltagi's (1995, pp. 3-6) observations, or Shrivastav and Kalsie (2015), this model's most important advantages are as follows:

- Considering the multitude of data for cross-sectional and time series, the degree of data heterogeneity increases. In addition, the panel data model allows for the use of variables that reflect the differences between the classes/cross-sectional entities used (as we will later use the fixed effects by using dummy variables).

- By combining time and cross-sectional series, we obtain several observations and degrees of freedom: and

- The model is much more suitable for reflecting the dynamics of the changes in time of the analyzed phenomenon.

The model used is a multifactorial regression equation with fixed effects, meant to highlight the various profiles of companies according to the turnover achieved (leverage effect and recorded returns). According to the observations of Gujarati (page 637), in this case, dummy variables that do not vary in time, but differ for each cross-sectional category (the five classes of companies according to the recorded turnover) should be used. Because the estimated values for the dummy variables are incidental (the difference from the cross-sectional series used as a reference), we will use a number of four dummy variables, the constant of the multifactorial regression equation being related to the first class of companies. Thus, the multifactorial regression equation becomes

$R O E_{i t}=\alpha_{1}+\alpha_{2} * D_{2 i}+\alpha_{3} * D_{3 i}+\alpha_{4} * D_{4 i}+\alpha_{5} * D_{5 i}+\beta_{2} x B A N C I_{i t}+B_{3} x D_{i t}+\mu_{i t}$; where

- BANKS is the evolution of the debt ratio associated with loans contracted from credit institutions; and

- $\quad \mathrm{D}$ is the level of interest (including commissions and possible penalties) related to the contracted financial loans.

\section{Results}

By applying the multifactorial regression equation previously described in the data panel in E-Views, we obtain the following result: 
Table 2. E-views results

$$
\begin{gathered}
\text { Dependent Variable: Return on equity (ROE)? } \\
\text { Method: Pooled Least Squares } \\
\text { Date: } 01 / 25 / 19 \text { Time: } 22: 41
\end{gathered}
$$

Sample: 20082017

Included observations: 10

Number of cross-sections used: 5

Total panel (balanced) observations: 50

\begin{tabular}{ccccc}
\hline Variable & Coefficient & Std. Error & t-Statistic & Prob. \\
\hline DEBT & -0.391482 & 0.215873 & -1.813485 & 0.0767 \\
D & 1.428763 & 0.635205 & 2.249293 & 0.0297
\end{tabular}

Fixed Effects

$\begin{array}{cccc}\text {-01--C } & 0.059086 & & \\ -02--C & 0.120337 & & \\ -03--C & 0.168299 & & \\ -04--C & 0.115994 & & \\ -05--C & 0.231550 & & 0.122956 \\ \text { R-squared } & 0.238192 & \text { Mean dependent var } & 0.124292 \\ \text { Adjusted R-squared } & 0.131893 & \text { S.D. dependent var } & 0.576675 \\ \text { S.E. of regression } & 0.115806 & \text { Sum squared resid } & 13.44464 \\ \text { Log likelihood } & 40.61555 & \text { F-statistic } & 0.000672 \\ \text { Durbin-Watson stat } & 1.423989 & \text { Prob(F-statistic) } & \end{array}$

Thus, the equation becomes:

$\widehat{\operatorname{ROE}}_{i t}=$

$0.059086+0.120337 * D_{2 i}+0.168299 * D_{3 i}+0.115994 * D_{4 i}+0.231550 * D_{5 i}-0.391482 *$ $D E B T_{i t}+1.428763 * D_{i t}+\mu_{i t}$;

Interpretation:

- $\quad$ If the volume of contracted credits (D) increases by $100 \mathrm{bp}$ (base points), respectively $1 \%$, then the financial return (ROE) decreases by 39 bp (0.39\% respectively); and

- $\quad$ if the interest rate on outstanding loans grows by $100 \mathrm{bp}$, then the financial return increases by $142 \mathrm{bp}(1.42 \%)$.

Apparently, cheaper financing encourages investment because it boosts consumption and reduces the financial burden for company development. Despite this, the results seem to contradict this idea, as rising interest rates are correlated with a higher return on capital of the companies analyzed. To answer this question, we have analyzed the evolution of all investment projects carried out by all active companies in Romania. In practical terms, we pursued the following steps (methodology):

- We considered all companies for which the increase in non-current assets exceeded $10 \%$ and the net value of the investments made exceeded RON 100,000 (practically speaking, these are companies that have made significant investments in the long run).

- We calculated the return on assets (ROA, return on assets = net profit / assets) obtained by these companies for the next three years, immediately after making the respective investments; and

- We repeated this exercise for each year of the period between 2010 and 2015 (for the last two years we can see the evolution of return up to and including year 2016).

The results are illustrated in the following table and Figure, and the conclusion is straightforward and obvious: the best investments were made when the cost of financing was high and the access to financing was difficult. The 
worst investments are made when the money is obtained easily and cheaply. Thus, the investments made during the period 2010-2012, when the level of ROBOR (Romania's money market rate) with a 3-month maturity was the highest and access to financing was most difficult (because of the high provisioning generated by the non-performing loans ratio), were the only ones that generated a return of more than 5\% in the first year and more than $10 \%$ after three years from the time of the investment. In contrast, investments made during the period 2013-2015 proved inefficient because they would not generate a return higher than the cost of financing.

Table 3. Return on investment in Romania

\begin{tabular}{cccccc}
\hline Year & NPL & $\begin{array}{c}\text { Loan } \\
\text { Interest }\end{array}$ & $\begin{array}{c}\text { ROA } \\
(\boldsymbol{T}+\mathbf{1})\end{array}$ & $\begin{array}{c}\boldsymbol{R O A} \\
(\boldsymbol{T}+2)\end{array}$ & $\begin{array}{c}\boldsymbol{R O A} \\
(\boldsymbol{T}+3)\end{array}$ \\
\hline $\mathbf{2 0 1 0}$ & $11.9 \%$ & $11.4 \%$ & $5.2 \%$ & $9.7 \%$ & $15.0 \%$ \\
$\mathbf{2 0 1 1}$ & $14.3 \%$ & $9.7 \%$ & $5.4 \%$ & $8.1 \%$ & $13.5 \%$ \\
$\mathbf{2 0 1 2}$ & $18.2 \%$ & $9.6 \%$ & $5.1 \%$ & $9.4 \%$ & $11.8 \%$ \\
$\mathbf{2 0 1 3}$ & $21.9 \%$ & $8.7 \%$ & $3.3 \%$ & $5.4 \%$ & $6.2 \%$ \\
$\mathbf{2 0 1 4}$ & $13.9 \%$ & $6.5 \%$ & $0.9 \%$ & $2.3 \%$ & \\
$\mathbf{2 0 1 5}$ & $11.3 \%$ & $4.8 \%$ & $-1.8 \%$ & & \\
\hline
\end{tabular}

Source - data processed by the author on the basis of financial statements (balance sheet, profit and loss account) submitted to the Ministry of Public Finance

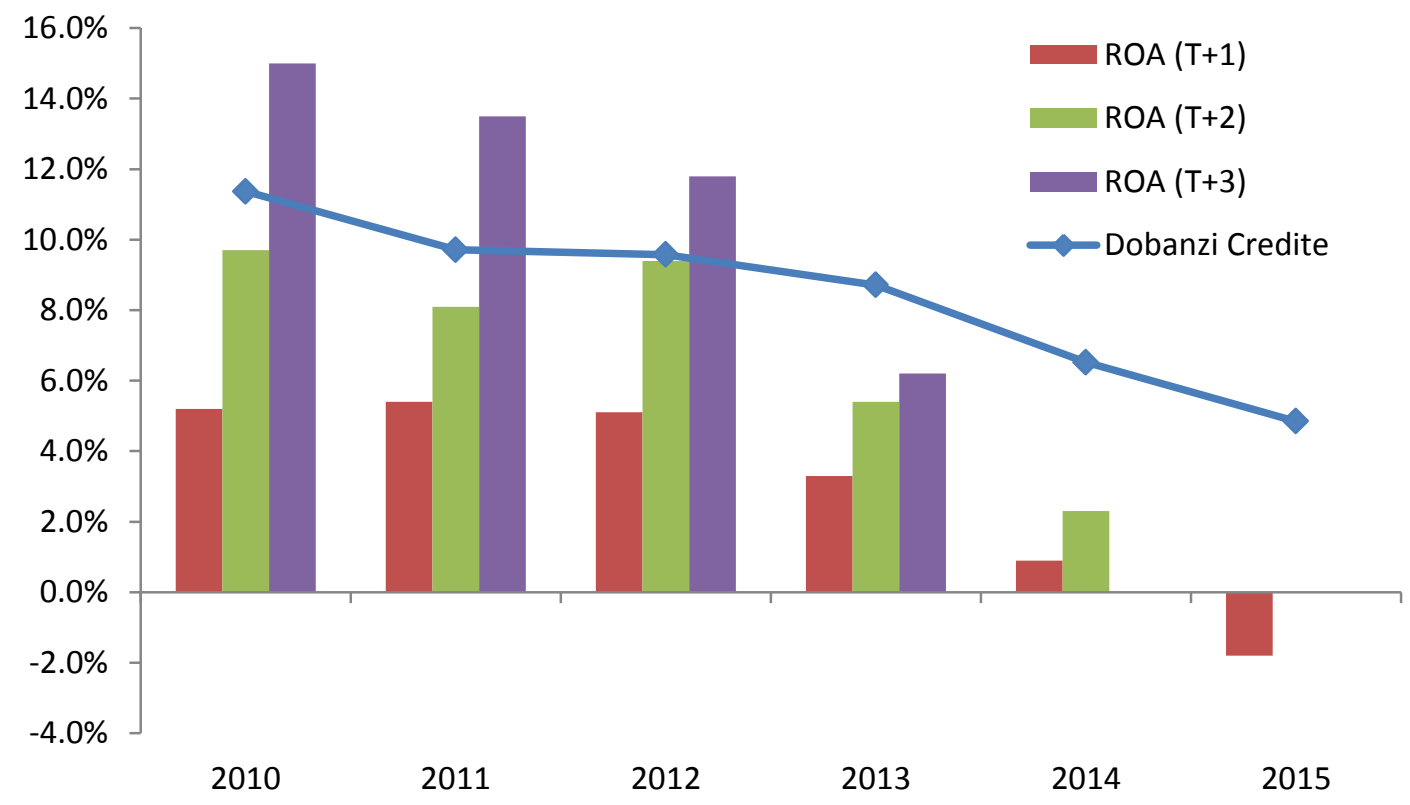

Figure 1. Return on investment vs. financing cost

R-squared is an important indicator that shows whether the model is well specified. It indicates what percentage of the total variance of the dependent variable is due to the independent variables, using the following formula:

R-squared $=($ TSS-SSE $) /$ TSS $=$ RSS $/$ TSS $=0.2381$.

The more the value of this indicator tends to 1 , the more well specified the model is. In our case, only $23.81 \%$ of the financial return variance is explained by the volume of contracted loans and the level of interest rates on the outstanding loans.

The R-squared indicator grows as new independent variables are added to the multifactorial regression equation, but it also causes the loss of the degrees of freedom. Therefore, an adjusted measure of R-squared is better because it 
considers the number of independent variables included in the regression (Codarlasu and Ghidesciuc, p. 44). The latter is calculated using the following formula:

$$
\mathrm{R}^{2}=1-\left((\mathrm{n}-1 /(\mathrm{n}-\mathrm{k})) *\left(1-\mathrm{R}^{2}\right)\right.
$$

where $\mathrm{n}$ is the number of observations and $\mathrm{k}$ is the number of independent variables included in the regression.

The E-Views results indicate a value of $13.18 \%$ for the adjusted R-squared coefficient, which is significantly below that of the R-squared coefficient.

\section{t-Test}

To test whether the estimated coefficients are statistically significant (different from zero), we can use the t-test, the hypotheses of which are as follows:

$H_{0}: \beta_{1}=0$

$H_{1}: \beta_{1} \neq 0$

According to the E-Views results, the t-test values for the two exogenous (independent) variables are

-1.813485 (DEBT) and 2.249293 (D).

Given that the associated probability is below the level of relevance (5\% for the interest rates and $10 \%$ for the credit volume), the null hypothesis is rejected and the coefficient is considered statistically significant with a confidence degree of $90 \%$ for the volume of loans and $95 \%$ for interest rates. This can also be verified through the fact that the displayed value of the t-test is higher than the critical value.

\section{F-test}

This test indicates the extent to which a set of independent variables explains, as a group, the variance of the dependent variable and determines the extent to which all coefficients of the regression equation simultaneously have zero values The hypotheses are as follows:

$H_{0}: \beta_{1}=\beta_{2}=0$,

$H_{1}: \beta_{1} \neq \beta_{2} \neq 0$

The value of the F-test calculated by E-views is 13.44464 and is obtained by using the following formula:

$F=(m-1) /\left(1-R^{2}\right)=(7-1) /(1-0,2382)=13.44464$

The F-test follows an $F$ distribution, and the critical value is determined as follows: $F_{c}=F_{\alpha ; m-1 ; n-m}=F(0,05 ; 6 ; 43)=2,34$. Given that the calculated value (13.44) is higher than the critical value (2.34), the null hypothesis is rejected, which means that at least one of the coefficients of the regression equation is statistically significant. We obtain the same conclusion if we observe that the associated probability is below the level of relevance $(5 \%)$ being used.

In accordance with the DuPont model, two independent variables were added to improve the econometric model: the operating result (EBIT: turnover) and asset turnover (ATO = assets / turnover).

By applying the multifactorial regression equation previously described on the data panel in E-Views, we obtain the following result: 
Table 4. E-views results

\begin{tabular}{|c|c|c|c|c|}
\hline \multicolumn{5}{|c|}{ Dependent Variable: Return on equity (ROE)? } \\
\hline \multicolumn{5}{|c|}{ Method: Pooled Least Squares } \\
\hline \multicolumn{5}{|c|}{ Date: 01/28/19 Time: $23: 47$} \\
\hline \multicolumn{5}{|c|}{ Sample: 20082017} \\
\hline \multicolumn{5}{|c|}{ Included observations: 10} \\
\hline \multicolumn{5}{|c|}{ Number of cross-sections used: 5} \\
\hline \multicolumn{5}{|c|}{ Total panel (balanced) observations: 50} \\
\hline Variable & Coefficient & Std. Error & $t$-Statistic & Prob. \\
\hline DEBT & -0.511301 & 0.180577 & -2.831483 & 0.0071 \\
\hline $\mathrm{D}$ & 0.554477 & 0.593887 & 0.933641 & 0.3560 \\
\hline EBIT & 1.289169 & 0.323008 & 3.991132 & 0.0003 \\
\hline ATO & 0.121998 & 0.049801 & 2.449699 & 0.0187 \\
\hline \multicolumn{5}{|l|}{ Fixed Effects } \\
\hline -01--C & -0.052160 & & & \\
\hline$-02--\mathrm{C}$ & -0.013545 & & & \\
\hline -03--C & -0.062767 & & & \\
\hline _04--C & -0.045912 & & & \\
\hline$-05--\mathrm{C}$ & -0.038100 & & & \\
\hline R-squared & 0.503145 & Mean d & dent var & 0.122956 \\
\hline Adjusted R-squared & 0.406197 & S.D. $\mathrm{de}$ & dent var & 0.124292 \\
\hline S.E. of regression & 0.095778 & Sum sc & d resid & 0.376111 \\
\hline Log likelihood & 51.30045 & $\mathrm{~F}-$ & tic & 13.83966 \\
\hline Durbin-Watson stat & 1.576804 & Prob( & tistic) & 0.000002 \\
\hline
\end{tabular}

\section{Thus, the following conclusions may be drawn:}

- the increase of the R-square to $50 \%$, which means that almost half of the financial return fluctuation is explained by the evolution of the four independent variables.

- $\quad$ all coefficients are statistically relevant, except for the interest rates applied to newly contracted loans (for which the associated probability is higher than the level of relevance); and

- $\quad$ the positive impact of the operating profit and asset turnover on financial return, whereas financial leverage has a negative consolidated effect (reflecting that company indebtedness adversely affects financial profitability),

- $\quad$ if the the operating result (EBIT: Turnover) increases by $100 \mathrm{bp}$ (base points), respectively $1 \%$, then the financial return (ROE) increase with $1,28 \mathrm{bp}(128 \%$ respectively)

- $\quad$ if the asset turnover (ATO = Assets / Turnover) grows by $100 \mathrm{bp}$, then the financial return increases by $12 \mathrm{bp}$ $(1,2 \%)$.

This conclusion is also evident from the analysis of the DuPont model for all companies active in the sector of wholesale trade of motor vehicle parts and accessories (NACE: 4531), which records revenues of more than EUR 1 million, according to the figures shown in the Figures and table below. 
Table 5. Financial Profitability - DuPont (5 factors)

\begin{tabular}{|c|c|c|c|c|c|c|}
\hline Year & $\begin{array}{c}E A T: \\
E B T\end{array}$ & $\begin{array}{l}E B T: \\
E B I T\end{array}$ & $\begin{array}{c}\text { EBIT: } \\
C A\end{array}$ & $\begin{array}{c}\text { Turnover / } \\
\text { Assets }\end{array}$ & $\begin{array}{c}\text { Assets: } \\
\text { Shareholder's } \\
\text { Equity }\end{array}$ & $R O E$ \\
\hline 2008 & $83.1 \%$ & $74.5 \%$ & $7.9 \%$ & 2.00 & 2.95 & $28.8 \%$ \\
\hline 2009 & $82.6 \%$ & $81.2 \%$ & $6.6 \%$ & 1.77 & 2.68 & $21.1 \%$ \\
\hline 2010 & $77.1 \%$ & $83.2 \%$ & $4.6 \%$ & 1.87 & 2.57 & $14.0 \%$ \\
\hline 2011 & $80.8 \%$ & $80.7 \%$ & $4.1 \%$ & 1.78 & 2.79 & $13.4 \%$ \\
\hline 2012 & $35.2 \%$ & $34.8 \%$ & $1.9 \%$ & 1.55 & 3.38 & $1.2 \%$ \\
\hline 2013 & $48.1 \%$ & $34.7 \%$ & $2.2 \%$ & 1.69 & 3.42 & $2.1 \%$ \\
\hline 2014 & $84.9 \%$ & $83.5 \%$ & $5.5 \%$ & 1.63 & 3.11 & $19.9 \%$ \\
\hline 2015 & $77.8 \%$ & $75.0 \%$ & $3.7 \%$ & 1.43 & 3.49 & $10.7 \%$ \\
\hline 2016 & $37.4 \%$ & $53.9 \%$ & $2.0 \%$ & 1.69 & 2.54 & $1.7 \%$ \\
\hline 2017 & $85.7 \%$ & $91.8 \%$ & $4.2 \%$ & 1.62 & 2.66 & $14.3 \%$ \\
\hline
\end{tabular}

Source: Ministry of Public Finance, National Trade Register Office, data processed by the author

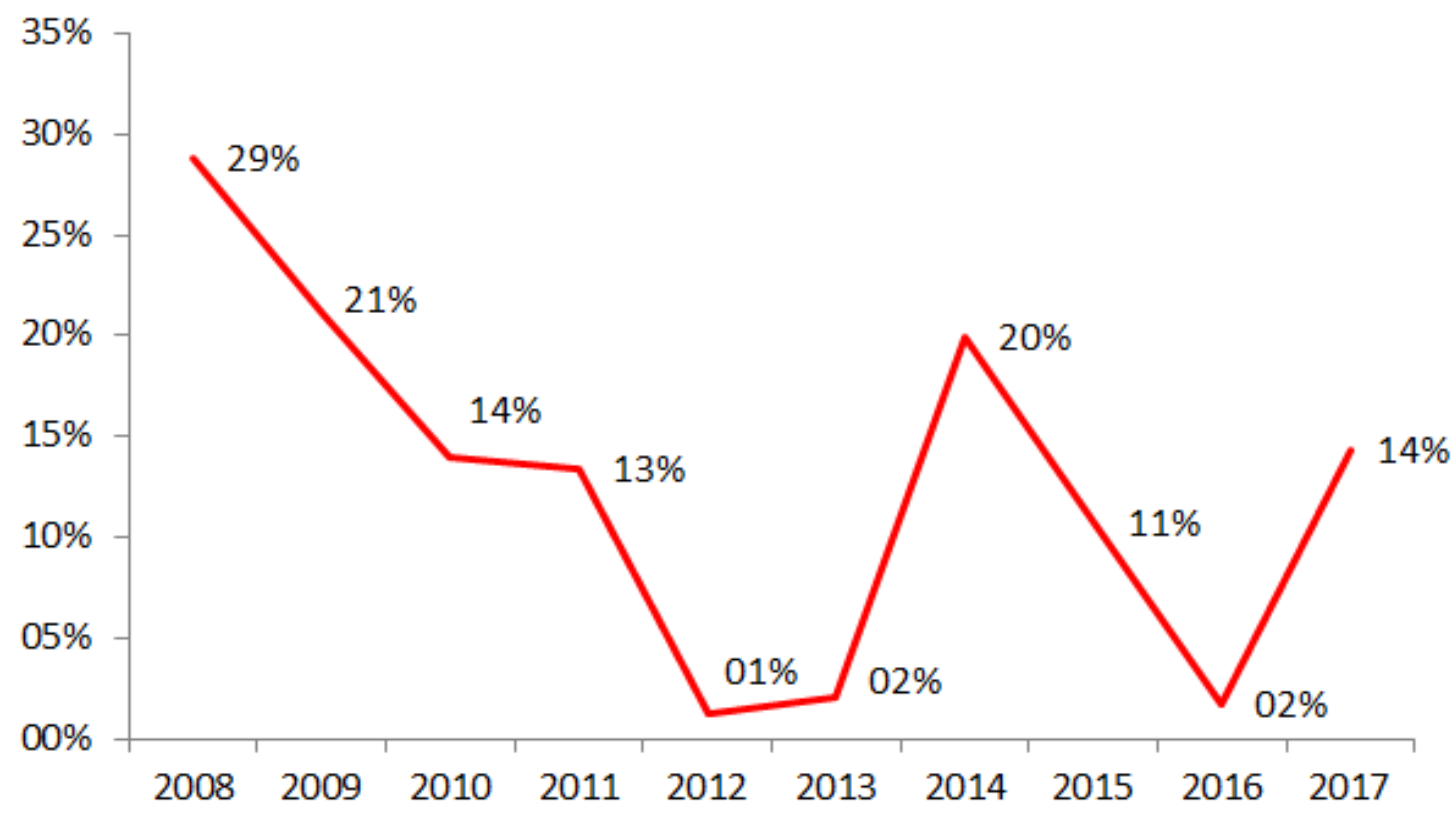

Figure 2. ROE evolution 


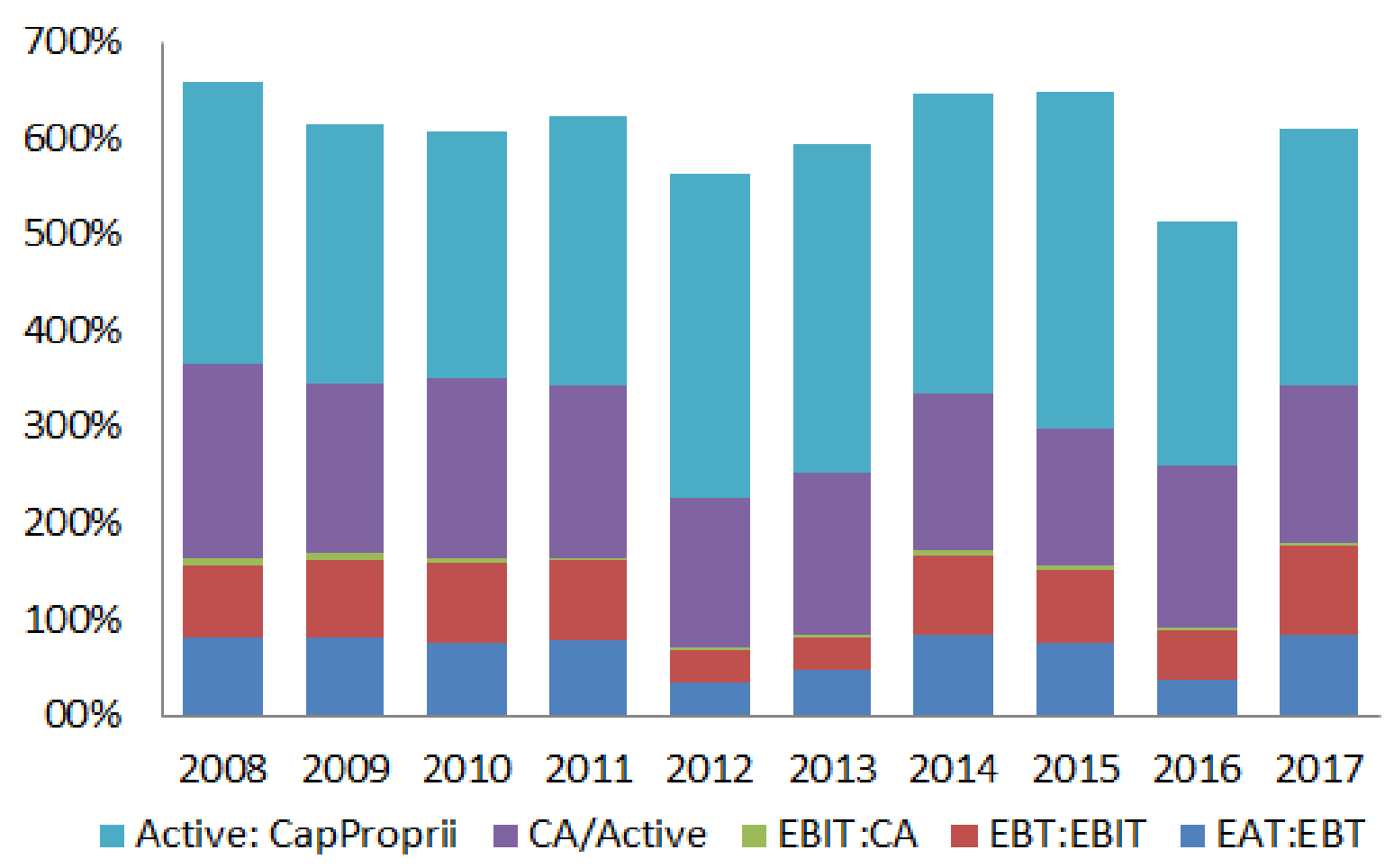

Figure 3. ROE (DuPont 5 factors)

\section{Conclusions}

This study analyzes the theoretical hypotheses regarding the dependence between financial profitability (as a dependent, endogenous variable) and bank credit (the volume of bank credits and the cost of borrowed capital, both expressed as independent, exogenous variables), by applying the panel data model to all companies in the sector of wholesale trade of parts and accessories for motor vehicles (NACE: 4531) that records revenues of more than EUR 1 million during the period 2008 to 2017.

In analyzing the dynamics of the sector for the period 2008 to 2015 , we notice a $48 \%$ increase in revenue, whereas the number of active companies has dropped by $25 \%$. In this context, the sector shows a general tendency toward increasing the degree of concentration among the most important players (reporting revenues higher than EUR 50 million), the cumulated market share of these companies having risen from 7.13\% (year 2008) to almost 34\% (year 2017). The insufficiency of equity resulting from modest profitability margins has led to a general increase in the indebtedness (debt ratio) of the companies in the sector.

Following the application of the presented model, we notice that only $24 \%$ of the financial return variance is explained by the bank credit (the volume of bank loans and the cost of the borrowed capital, both expressed as independent, exogenous variables). Thus, two additional variables were added to improve the model: operating return and asset turnover, which contributed to the increase of the relevant indicator to almost $50 \%$.

Given the high degree of concentration of the sector and the fact that firms recording revenues of more than EUR 1 million report a consolidated market share of about $74 \%$, this study deepens the diagnosis of the return on capital for these companies by decomposing it into margin, turnover and capital structure rates. Having applied the DuPont model for this purpose, we conclude as follows:

- The main source of generating financial returns for companies in the analyzed sample operating profit and asset turnover.

- The contribution of the operating profit to generating financial profitability declined steadily over the period 2008-2012 (mainly because of the adverse effects of the international financial crisis at local level), after which followed a steady increase in the operating return over the period 2013-2017, which contributed to an increase of the return on capital; 
- A similar trend, noticed in the case of asset turnover, which decreased from 2\% (2008) to just 1.55 (2012), followed by an increase to 1.62 (2017); and

- In this context, a steady decline recorded by ROE over the period 2008-2012, from $28 \%$ to just $1 \%$, followed by an increase to $14.3 \%$ in year 2017 .

For the purpose of future research, it is advisable to perform a sensitivity analysis of financial return in relation to various stress scenarios regarding the fluctuation of the financing cost, given the inflationary pressures existing in Romania in the last two years.

\section{References}

Alcock, J. \& Steiner, E. (2017). Unexpected inflation, capital structure, and real risk-adjusted firm performance. Abacus, 53(2), 273-298. https://doi.org/10.1111/abac.12102

Anthony, J. (2011). Firm size, capital structure and earnings announcement price response. Journal of Applied Business Research (JABR), 24(1), 24-32.

Avc1, E. (2016). Capital structure and firm performance: An application on manufacturing industry. İktisadi ve İdari Bilimler Dergisi, 38(1), 15-30.

Baltagi, B. H. (1995). Econometric Analysis of Panel Data. Wiley.

Beard, C. G. \& Sias, R. W. (1997). Is there a neglected-firm effect? Financial Analysts Journal, 53(5), 19-23.

Burns, D. C., Sale, J. T. \& Stephan, J. A. (2008). A better way to gauge profitability. Journal of Accountancy, 206(2), 38.

Cace, S., Arpinte, D., Cace, C. \& Cojocaru, Ş. (2011). The social economy. An integrating approach. Transylvanian Review of Administrative Sciences, 33(E), 49-66.

Codarlasu, A. \& Ghidesciuc, N. (2008). Econometrie Aplicata (44-55). Publisher.

Colbu, I. C. (2013). Comparison of profitability for pharmaceutical Romanian listed companies using DuPont identity. Public Administration, 13(1), 17-35.

Gujarati, D. (2004). Basic econometrics (4 ${ }^{\text {th }}$ ed.). The McGraw-Hill Companies, 637-643.

Guo, Zy. \& Luo, Y (2017). Credit Constraint Exports in Countries with Different Degrees of Contract Enforcement. Business and Economic Research, 7(1), 227-241. https://doi.org/10.5296/ber.v7i1.10923

Halsey, R. F. (2001). Using the residual-income stock price valuation model to teach and learn ratio analysis. Issues in Accounting Education, 16(2), 257-272.

Kasilingam, R. \& Jayabal, G. (2012). Profitability and solvency analysis of a manufacturing company using Dupont and Altman Model. BVIMR Management Edge, 5(2), 31-50.

Kim, C. J., Morley, J. C. \& Nelson, C. R. (2005). The structural break in the equity premium. Journal of Business \& Economic Statistics, 23(2), 181-191. https://doi.org/10.1198/073500104000000352

Miglo, A. (2017). Timing of earnings and capital structure. North American Journal of Economics and Finance, 40, $1-15$.

Muradoğlu, Y. \& Sivaprasad, S. (2012). Capital structure and abnormal returns. International Business Review, 21(3), $328-341$.

Nissim, D. \& Penman, S. H. (2003). Financial statement analysis of leverage and how it informs about profitability and price-to-book ratios. Review of Accounting Studies, 8(4), 531-560.

Shrivastav, S. M. \& Kalsie, A. (2015). Board composition and firm performance: panel-level analysis of firms in emerging market. Journal of Contemporary Research in Management, 10(3), 17-29.

Stancu, D. \& Stancu, I. (2012). Finante corporative cu Excel (Corporate Finance with Excel). Economica.

Vijayakumaran, R. (2018). Capital structure decisions and corporate performance: Evidence from Chinese-listed industrial firms. International Journal of Accounting and Financial Reporting, 7(2), 562-580. SSRN: https://ssrn.com/abstract=3165912

Wibowo, A. (2005). Discussion of "Optimal capital structure model for bot power projects in Turkey" by Sandalkhan Bakatjan, Metin Arikan, and Robert L. K. Tiong. Journal of Construction Engineering and Management, 131(3), 385-386. https://doi.org/10.1061/(ASCE)0733-9364(2005)131:3(385) 